\title{
Cortistatin-17 and -14 exert the same endocrine activities as somatostatin in humans
}

\author{
C. Gottero ${ }^{\text {a }}$, F. Prodam ${ }^{\text {a }}$, S. Destefanis ${ }^{\text {a }}$, A. Benso ${ }^{\text {a }}$, C. Gauna ${ }^{\text {b }}$, E. Me ${ }^{\text {a }}$, L. Filtri $^{\text {a }}$, \\ F. Riganti ${ }^{a}$, A.J. van der Lely ${ }^{b}$, E. Ghigo ${ }^{a, *}$, F. Broglio ${ }^{\text {a,b }}$ \\ ${ }^{a}$ Division of Endocrinology and Metabolism, Department of Internal Medicine, University of Turin, c.so Dogliotti 14, 10126 Turin Italy \\ ${ }^{\mathrm{b}}$ Division of Endocrinology, Department of Internal Medicine, Erasmus University of Rotterdam, The Netherlands
}

Received 12 January 2004; received in revised form 27 April 2004; accepted 28 April 2004

\begin{abstract}
Cortistatin (CST) is a neuropeptide, which binds with high affinity all somatostatin (SS) receptor subtypes and shows high structural homology with SS itself. A receptor specific for CST only, i.e., not recognized by SS, has been recently described in agreement with data reporting that not all CST actions are shared by SS. Interestingly, CST but not SS also binds ghrelin receptor (GHS-R1a) in vitro, suggesting a potential interplay between CST and ghrelin system. The aim of this study was to investigate in humans the endocrine and metabolic activities of human CST-17 in comparison with rat CST-14 that has previously been shown to exert the same endocrine actions of SS in healthy volunteers. To this aim, in six healthy male volunteers (age [median, 3rd-97th centiles]: 28.5; 23.6-34.3 years; Body Mass Index: 23.5; 21.0-25.1 kg/m²), we studied the effects of human CST-17 $(2.0 \mu \mathrm{g} / \mathrm{kg} / \mathrm{h}$ iv over $120 \mathrm{~min})$, rat CST-14 $(2.0 \mu \mathrm{g} / \mathrm{kg} / \mathrm{h}$ iv over $120 \mathrm{~min})$ and SS-14 $(2.0 \mu \mathrm{g} / \mathrm{kg} / \mathrm{h} \mathrm{iv} \mathrm{over}$ $120 \mathrm{~min}$ ) on: (a) spontaneous GH, ACTH, PRL, cortisol, insulin and glucose levels; (b) the GH responses to GHRH (1.0 $\mu \mathrm{g} / \mathrm{kg}$ iv at $0 \mathrm{~min})$; (c) the GH, PRL, ACTH, cortisol, insulin and glucose responses to ghrelin (1.0 $\mu \mathrm{g} / \mathrm{kg}$ iv at $0 \mathrm{~min})$. CST-17 inhibited $(p<0.01)$ basal GH secretion to the same extent of CST-14 and SS-14. Spontaneous PRL, ACTH and cortisol secretion were not significantly modified by CST-17, CST-14 or SS-14. CST-17 as well as CST-14 and SS-14 also inhibited $(p<0.05)$ spontaneous insulin secretion to a similar extent. None of these peptides modified glucose levels. The GH response to GHRH was inhibited to the same extent by CST-17 $(p<0.01)$, CST-14 $(p<0.01)$ and SS-14 $(p<0.05)$. The ghrelin-induced GH response was higher than that elicited by GHRH $(p<0.01)$ and inhibited by CST-17 $(p<0.05)$ as well as by CST-14 $(p<0.05)$ and SS-14 $(p<0.01)$. The PRL, ACTH and cortisol responses to ghrelin were unaffected by CST-17, CST-14 or SS14. On the other hand, the inhibitory effect of ghrelin on insulin levels was abolished by CST-17, CST-14 or SS-14 ( $p<0.05)$ that, in turn, did not modify the ghrelin-induced increase in glucose levels. In conclusion, this study demonstrates that human CST-17 and rat CST-14 exert the same endocrine activities of SS in humans. The endocrine actions of human and rat CST therefore are likely to reflect activation of classical SS receptors.
\end{abstract}

(C) 2004 Elsevier Ltd. All rights reserved.

Keywords: Cortistatin; Somatostatin; GH; GHRH; Ghrelin; PRL; ACTH; Cortisol; Insulin; Glucose

\section{Introduction}

Cortistatin (CST) is a neuropeptide expressed mainly in the cortex and hippocampus and, more recently, also found in peripheral tissues such as stomach, kidney, immune system and pancreas [1-7]. Interestingly, pre-

\footnotetext{
${ }^{*}$ Corresponding author. Tel.: +39-011-633-4336/4317; fax: +39-011664-7421.

E-mail address: ezio.ghigo@unito.it (E. Ghigo).
}

pro-CST shows high structural homology with prepro-somatostatin (-SS) and generates two mature products, CST-14 and CST-29 in rat $[1,2]$ and two, CST-17 and CST-29, in human [1-4].

SS exerts its multiple biological effects via membranebound receptors of which five subtypes have been cloned $[8,9]$. CST-17, CST-14 and CST-29 bind all SS receptor subtypes with an affinity close to that of SS and therefore were expected to have similar biological activities $[3,4,10]$. However, the existence of specific receptors able to bind 
CST only has been hypothesized based on evidence that not all CST actions overlap with those of SS [4,10-12]. Moreover, even when co-expressed in the same neurons, CST and SS are regulated by different stimuli $[2,4,13]$.

In agreement with this hypothesis, a previously orphan G-protein coupled receptor, named MrgX2, expressed in dorsal root ganglions, testis, small intestine, spinal cord, pancreas, lung, heart, thymus and colon, has been recently described as being able to selectively bind both CST-17 and CST-14 but not SS [14].

On the other hand, in human tissues, CST-17 as well as CST-14, but not SS, bind the GH secretagogues receptor (GHS-R), an endogenous ligand of which is ghrelin [15-17].

Ghrelin is an acylated 28 amino-acid peptide mostly synthesized in the stomach but also expressed in several other central and peripheral endocrine and non-endocrine tissues $[16,18,19]$. Ghrelin exerts several central and peripheral endocrine and non-endocrine actions including a stimulatory effect on somatotroph, lactotroph and corticotroph secretion and a modulatory influence on insulin secretion and glucose metabolism [16,18-20].

Evidence that CST displaces ghrelin binding from its receptor would have predicted that CST, differently from SS, has some interaction with ghrelin system [17]. Notice that the MrgX2 has been shown specific for CST but is unable to bind GHS [14].

Indeed, rat CST-14 has already been demonstrated to be an active peptide in humans and in rats in whom it displays similar endocrine actions to those of SS-14 [17,21-24].

The activities of human CST isoforms in humans, however, have never been investigated so far. As one single amino-acid mutation is enough to completely change the biological profile of a peptide [25], we decided to compare the endocrine actions of human CST with those of rat CST and SS-14 in healthy young volunteers. Specifically, we studied the effects of human CST-17 on: (a) spontaneous GH, ACTH, PRL, cortisol, insulin and glucose levels; (b) the $\mathrm{GH}$ responses to GHRH; (c) the GH, PRL, ACTH, cortisol, insulin and glucose responses to ghrelin.

\section{Subjects and methods}

Six healthy young male volunteers [median; 3rd-97th centiles] (age: 28.5 ; 23.6-34.3 years; Body Mass Index: $23.5 ; 21.0-25.1 \mathrm{~kg} / \mathrm{m}^{2}$ ) were studied.

All subjects gave their written informed consent to participate in the study which had been approved by an independent Ethical Committee.

All subjects underwent the following testing sessions in random order at least three days apart:

\subsection{Study 1}

(1.a) Saline;

(1.b) CST-17 $(2.0 \mu \mathrm{g} / \mathrm{kg} / \mathrm{h}$ iv over $120 \mathrm{~min}$ from 0 to $+120 \mathrm{~min})$

(1.c) CST-14 $(2.0 \mu \mathrm{g} / \mathrm{kg} / \mathrm{h}$ iv over $120 \mathrm{~min}$ from 0 to $+120 \mathrm{~min})$

(1.d) $\mathrm{SS}-14(2.0 \mu \mathrm{g} / \mathrm{kg} / \mathrm{h}$ iv over $120 \mathrm{~min}$ from 0 to +120 $\min )$.

\subsection{Study 2}

(2.a) GHRH $(1.0 \mu \mathrm{g} / \mathrm{kg}$ iv at $0 \mathrm{~min})$;

(2.b) Ghrelin $(1.0 \mu \mathrm{g} / \mathrm{kg}$ iv at $0 \mathrm{~min})$;

(2.c) GHRH $(1.0 \mu \mathrm{g} / \mathrm{kg}$ iv at $0 \mathrm{~min})+\mathrm{CST}-17(2.0 \mu \mathrm{g} /$ $\mathrm{kg} / \mathrm{h}$ iv over $120 \mathrm{~min}$ from -30 to $+90 \mathrm{~min}$ );

(2.d) $\mathrm{GHRH}(1.0 \mu \mathrm{g} / \mathrm{kg}$ iv at $0 \mathrm{~min})+\mathrm{CST}-14(2.0 \mu \mathrm{g} /$ $\mathrm{kg} / \mathrm{h}$ iv over $120 \mathrm{~min}$ from -30 to $+90 \mathrm{~min}$ );

(2.e) $\mathrm{GHRH}(1.0 \mu \mathrm{g} / \mathrm{kg}$ iv at $0 \mathrm{~min})+\mathrm{SS}-14(2.0 \mu \mathrm{g} / \mathrm{kg} / \mathrm{h}$ iv over $120 \mathrm{~min}$ from -30 to $+90 \mathrm{~min})$;

(2.f) Ghrelin $(1.0 \mu \mathrm{g} / \mathrm{kg}$ iv at $0 \mathrm{~min})+$ CST-17 $(2.0 \mu \mathrm{g} /$ $\mathrm{kg} / \mathrm{h}$ iv over $120 \mathrm{~min}$ from -30 to $+90 \mathrm{~min}$ );

(2.g) Ghrelin $(1.0 \mu \mathrm{g} / \mathrm{kg}$ iv at $0 \mathrm{~min})+\mathrm{CST}-14(2.0 \mu \mathrm{g} /$ $\mathrm{kg} / \mathrm{h}$ iv over $120 \mathrm{~min}$ from -30 to $+90 \mathrm{~min}$ );

(2.h) Ghrelin $(1.0 \mu \mathrm{g} / \mathrm{kg}$ iv at $0 \mathrm{~min})+\mathrm{SS}-14(2.0 \mu \mathrm{g} / \mathrm{kg} /$ $\mathrm{h}$ iv over $120 \mathrm{~min}$ from -30 to $+90 \mathrm{~min}$ );

After an overnight fast, testing sessions began in the morning at 08:30-09:00 h, 30 min after an indwelling catheter had been placed into an antecubital vein of the forearm kept patent by slow infusion of isotonic saline. None of the subjects were under treatment with any drug. Blood samples were taken every 15 min from -15 up to $+150 \mathrm{~min}$ in sessions (1.a)-(1.d). Blood samples were taken every $15 \mathrm{~min}$ from -30 up to $+120 \mathrm{~min}$ in sessions (2.a)-(2.h).

GH levels were assayed in all the sessions. PRL, ACTH, cortisol, insulin and glucose levels were assayed at each time point in sessions (1.a)-(1.d), (2.b), (2.f)-(2.h).

Serum GH levels $(\mu \mathrm{g} / 1 ; 1 \mu \mathrm{g} / \mathrm{l}=45.4 \mathrm{pmol} / \mathrm{l})$ were measured in duplicate by immunoradiometric assay (hGH-CTK IRMA, SORIN Biomedica, Saluggia, Italy). The sensitivity of the assay was $0.15 \mu \mathrm{g} / \mathrm{l}$. The inter- and intra-assay coefficients of variation were $2.9-4.5 \%$ and $2.4-4.0 \%$, respectively.

Serum PRL levels $(\mu \mathrm{g} / \mathrm{l} ; 1 \mu \mathrm{g} / \mathrm{l}=43.5 \mathrm{pmol} / \mathrm{l})$ were measured in duplicate by immunoradiometric assay (PRL-CTK, IRMA, SORIN Biomedica, Saluggia, Italy). The sensitivity of the assay was $0.5 \mu \mathrm{g} / \mathrm{l}$. The interand intra-assay coefficients of variation ranged from $3.9 \%$ to $6.8 \%$ and from $3.3 \%$ to $7.5 \%$, respectively.

Plasma ACTH levels (pg/ml; $1 \mathrm{pg} / \mathrm{ml}=0.2202 \mathrm{pmol} / \mathrm{l})$ were measured by immunoradiometric assay (ACTH, Nichols Institute Diagnostic, San Juan Capistrano, CA, USA). The sensitivity of the assay was $1 \mathrm{pg} / \mathrm{ml}$. The ranges of inter- and intra-assay coefficients of variation were $2.4-8.5 \%$ and $3.9-9.9 \%$, respectively. 
Serum cortisol levels $(\mu \mathrm{g} / \mathrm{l} ; 1 \mu \mathrm{g} / \mathrm{l}=2.759 \mathrm{nmol} / \mathrm{l})$ were measured in duplicate by radioimmunoassay (CORTCTK 125, IRMA, SORIN Biomedica, Saluggia, Italy). The sensitivity of the assay was $4.0 \mu \mathrm{g} / \mathrm{l}$. The inter- and intra-assay coefficients of variation ranged from $6.6 \%$ to $7.5 \%$ and from $3.8 \%$ to $6.6 \%$, respectively.

Serum insulin levels (mU/l; $1 \mathrm{mU} / \mathrm{l}=7.175 \mathrm{pmol} / \mathrm{l})$ were measured in duplicate by immunoradiometric assay (INSIK-5, SORIN Biomedica, Saluggia, Italy). The sensitivity of the assay was $2.5 \pm 0.3 \mathrm{mU} / \mathrm{l}$. The interand intra-assay coefficients of variation were $6.2-10.8 \%$ and $5.5-10.6 \%$, respectively.

Plasma glucose levels $(\mathrm{mg} / \mathrm{dl} ; 1 \mathrm{mg} / \mathrm{dl}=0.05551$ $\mathrm{mmol} / \mathrm{l}$ ) were measured by gluco-oxidase colorimetric method (GLUCOFIX, Menarini Diagnostici, Florence, Italy).

All samples from an individual subject were analyzed together.

The hormonal responses are expressed as delta or absolute values or areas under curves (AUCs) calculated by trapezoidal integration.

After demonstration by Shapiro-Wilk $W$ test that data were not Gaussian distributed, statistical analysis was carried out using non-parametric ANOVA (Friedman test) and then Wilcoxon test, as appropriate.

The results are expressed as median, 3rd and 97th centiles.

\section{Results}

\subsection{Study 1}

No significant changes of $\mathrm{GH}\left(\mathrm{AUC}^{0^{\prime} \rightarrow 120^{\prime}}: 40.1\right.$; 22.7-432.6 $\mu \mathrm{g} * \mathrm{~min} / \mathrm{l}), \mathrm{PRL}\left(\mathrm{AUC}^{0^{\prime} \rightarrow 120^{\prime}}: 596.3 ; 495.2-\right.$ $782.4 \mu \mathrm{g} * \mathrm{~min} / \mathrm{l})$, insulin $\left(\mathrm{AUC}^{0^{\prime} \rightarrow 120^{\prime}}: 1608.0 ; 1399.8-2\right.$ $107.6 \mathrm{mU} * \mathrm{~min} / \mathrm{l})$ and glucose $\left(\mathrm{AUC}^{0^{\prime} \rightarrow 120^{\prime}}: 8606.3 ; 8\right.$ 077.9-10102.5 $\mathrm{mg} * \mathrm{~min} / \mathrm{dl}$ ) levels were observed during saline administration. On the other hand, a significant $(p<0.05)$ trend toward decrease of spontaneous ACTH $\left(\mathrm{AUC}^{0^{\prime} \rightarrow 120^{\prime}}: 2256.0 ; 1813.3-2686.8 \mathrm{pg} * \mathrm{~min} / \mathrm{l}\right)$ and cortisol (AUC ${ }^{0^{\prime} \rightarrow 120^{\prime}}$ : 14 812.1; 11836.2-16927.9 $\mu \mathrm{g} * \mathrm{~min} / \mathrm{l}$ ) levels was observed.

CST-17 inhibited spontaneous GH secretion $\left(\mathrm{AUC}^{0^{\prime} \rightarrow 120^{\prime}}: 3.7 ; 1.6-8.0 \mu \mathrm{g} * \mathrm{~min} / 1, p<0.01\right)$ to the same extent of CST-14 (AUC ${ }^{0^{\prime} \rightarrow 120^{\prime}}$ : 5.6; 4.6-10.8 $\mu \mathrm{g} * \min / 1 ; p<0.01)$ and of SS-14 $\left(\mathrm{AUC}^{0^{\prime} \rightarrow 120^{\prime}}: 9.7 ; 1.8-\right.$ $18.2 \mu \mathrm{g} * \mathrm{~min} / 1 ; p<0.01$ ) (Fig. 1).

Spontaneous PRL, ACTH and cortisol secretion were not significantly modified by CST-17, CST-14 or SS-14 administration (data not shown).

CST-17 also inhibited $(p<0.05)$ spontaneous insulin secretion (AUC ${ }^{0^{\prime} \rightarrow 120^{\prime}}$ : 839.3; 837.1-1 $\left.117.0 \mathrm{mU} * \mathrm{~min} / \mathrm{l}\right)$ with a similar extent than CST-14 $\left(\mathrm{AUC}^{0^{\prime} \rightarrow 120^{\prime}}: 912.7\right.$; 426.2-1 759.7 $\mathrm{mU} * \mathrm{~min} / 1 ; \quad p<0.05)$ and $\mathrm{SS}-14$ $\left(\mathrm{AUC}^{0^{\prime} \rightarrow 120^{\prime}}:\right.$ 789.7; 447.0-1529.1 $\mathrm{mU} * \mathrm{~min} / \mathrm{l} ; p<0.01$ )

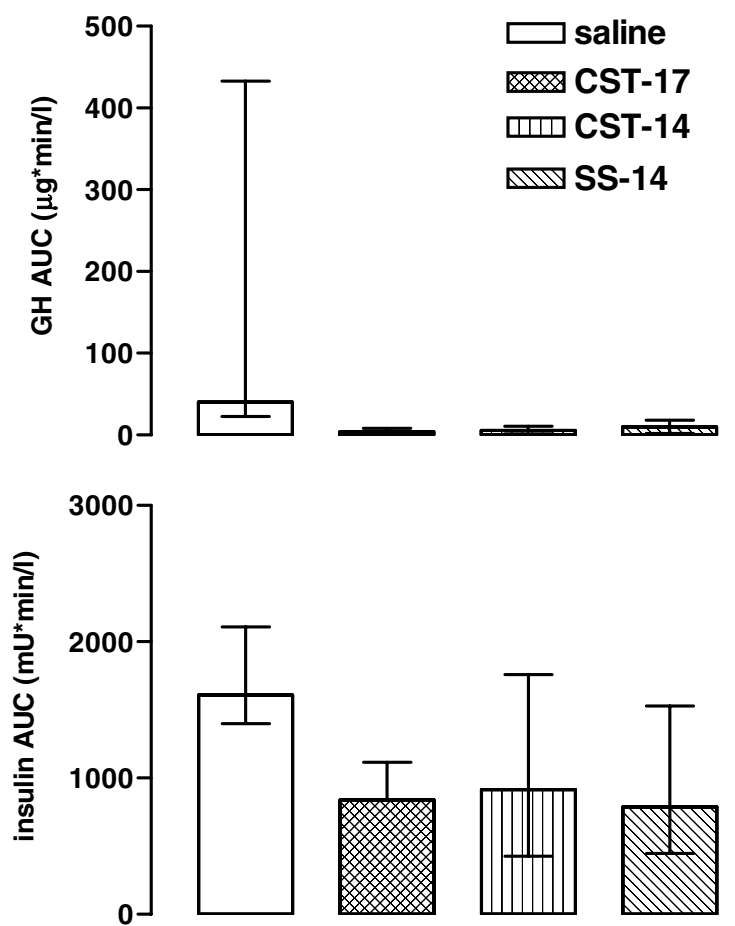

Fig. 1. Median, 3rd and 97th centiles of GH and insulin AUC during saline or CST-17 (2.0 $\mu \mathrm{g} / \mathrm{kg} / \mathrm{h}$ iv) or CST-14 (2.0 $\mu \mathrm{g} / \mathrm{kg} / \mathrm{h}$ iv) or SS-14 $(2.0 \mu \mathrm{g} / \mathrm{kg} / \mathrm{h}$ iv) administration in six normal subjects.

(Fig. 1). Significant and similar rebound increases of insulin levels after infusion withdrawal of either CST-17 $\left(\Delta\right.$ peak $^{135 \rightarrow 150}$ above time $120^{\prime}: 13.8 ; 11.6-16.1 \mathrm{mU} / \mathrm{l}$; $p<0.05)$ or CST-14 ( $\Delta$ peak $^{135 \rightarrow 150}$ above time $120^{\prime}$ : $14.4 ; 6.85-15.4 \mathrm{mU} / 1 ; p<0.05)$ or SS-14 $\left(\Delta\right.$ peak $^{135 \rightarrow 150}$ above time $\left.120^{\prime}: 12.3 ; 1.5-58.4 \mathrm{mU} / 1 ; p<0.05\right)$ were observed.

CST-17, CST-14 and SS-14 did not modify basal glucose levels (data not shown).

\subsection{Study 2}

CST-17 infusion inhibited the GH response to GHRH (AUC ${ }^{0 \rightarrow 90}: 140.3 ; 49.3-530.8$ vs. $969.7 ; 600.1-3$ $617.0 \mu \mathrm{g} * \mathrm{~min} / 1 ; p<0.01)$ to the same extent of CST-14 $\left(\mathrm{AUC}^{0 \rightarrow 90}: 282.0 ; 164.4-364.3 \mu \mathrm{g} * \mathrm{~min} / \mathrm{l} ; p<0.01\right.$ ) and SS-14 (AUC ${ }^{0 \rightarrow 90}: 226.5 ; 65.2-299.3 \mu \mathrm{g} \mathrm{min} / 1 ; p<0.05$ ). A significant rebound effect on GH levels after infusion withdrawal of either CST-17 $\left(\Delta\right.$ peak $^{105 \rightarrow 120}$ above time $\left.90^{\prime}: 8.6 ; 5.4-21.7 \mu \mathrm{g} / 1 ; p<0.05\right)$ or CST-14 $\left(\Delta\right.$ peak $^{105 \rightarrow 120}$ above time $\left.90^{\prime}: 5.2 ; 1.5-9.6 \mu \mathrm{g} / 1 ; p<0.05\right)$ or SS-14 $\left(\Delta\right.$ peak $^{105 \rightarrow 120}$ above time $90^{\prime}: 1.3 ; 0.4-12.3 \mu \mathrm{g} /$ $1 ; p<0.05)$ were observed even after the GHRH tests (Fig. 2).

Ghrelin induced a $\mathrm{GH}$ increase $\left(\mathrm{AUC}^{0 \rightarrow 90}: 5350.5\right.$; 2442.7-9151.8 $\mu \mathrm{g} * \mathrm{~min} / \mathrm{l} ; \quad p<0.01)$ that was higher $(p<0.01)$ than that elicited by GHRH. CST-17 inhibited $(p<0.05)$ the $\mathrm{GH}$ response to ghrelin $\left(\mathrm{AUC}^{0 \rightarrow 90}\right.$ : $2165.3 ; 1859.3-3212.9 \mu \mathrm{g} * \mathrm{~min} / \mathrm{l})$ to the same extent of 

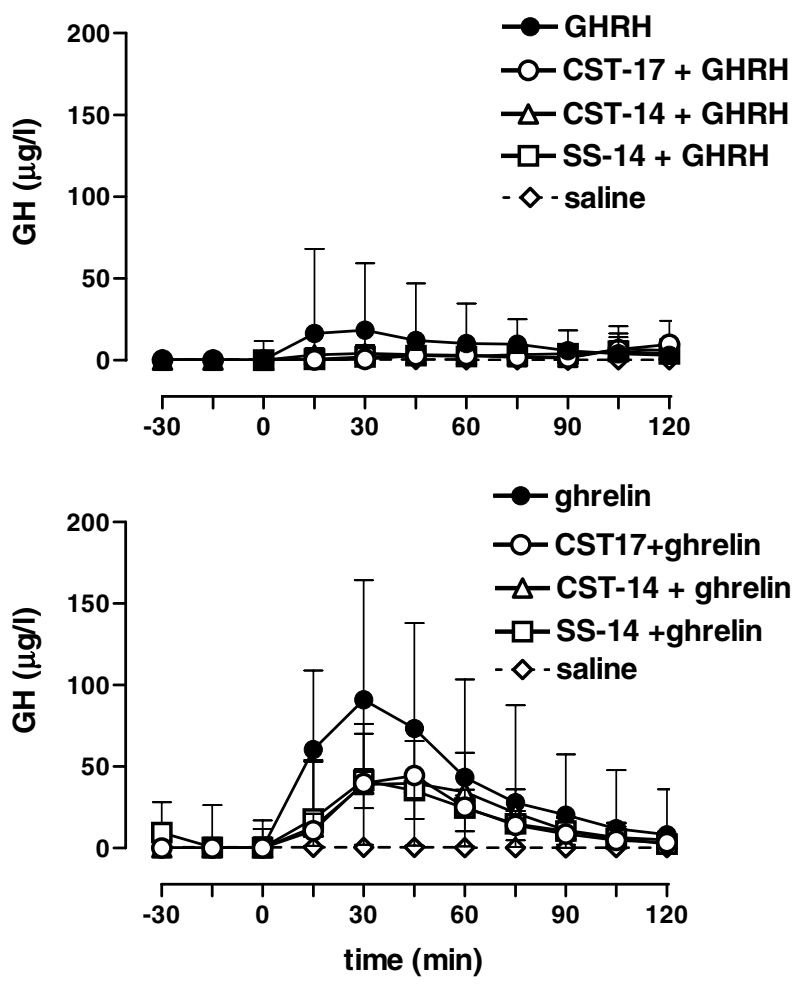

Fig. 2. Median, 3rd and 97th centiles of the GH responses to GHRH $\left(1.0 \mu \mathrm{g} / \mathrm{kg}\right.$ iv as a bolus at $\left.0^{\prime}\right)$ or ghrelin $\left(1.0 \mu \mathrm{g} / \mathrm{kg}\right.$ iv as a bolus at $\left.0^{\prime}\right)$ alone or in coadministration with CST-17 $\left(2.0 \mu \mathrm{g} / \mathrm{kg} / \mathrm{h}\right.$ iv from $-30^{\prime}$ to $\left.+90^{\prime}\right)$ or CST-14 $\left(2.0 \mu \mathrm{g} / \mathrm{kg} / \mathrm{h}\right.$ iv from $-30^{\prime}$ to $\left.+90^{\prime}\right)$ or SS-14 $(2.0 \mu \mathrm{g} / \mathrm{kg} /$ $\mathrm{h}$ iv from $-30^{\prime}$ to $+90^{\prime}$ ) in 6 normal subjects.

CST-14 (AUC ${ }^{0 \rightarrow 90}: 2252.1 ; 1093.5-4073.0 \mu \mathrm{g} * \mathrm{~min} / \mathrm{l}$; $p<0.05)$ and SS-14 (AUC ${ }^{0 \rightarrow 90}: 2374.9 ; 107.5-3086.2$ $\mu \mathrm{g} * \mathrm{~min} / 1 ; p<0.01)$, making them similar to that to GHRH alone (Fig. 2).

Unlike GHRH, no rebound effect on GH levels was observed after infusion withdrawal of either CST-17 or CST-14 or SS-14 (Fig. 2).

The PRL, ACTH and cortisol responses to ghrelin were not significantly modified by CST-17, CST-14 or SS-14 administration (data not shown).

Ghrelin administration also inhibited spontaneous insulin secretion $\left(\triangle \mathrm{AUC}^{0 \rightarrow 90}:-183.0 ;-408.2\right.$ to -110.0 $\mathrm{mU} * \min / 1 ; p<0.01)$. The inhibitory effect of ghrelin on insulin levels was almost abolished by CST-17 $\left(\Delta \mathrm{AUC}^{0 \rightarrow 90}:-73.5 ;-102.4-155.6 \mathrm{mU} * \mathrm{~min} / \mathrm{l} ; p<0.05\right)$, CST-14 ( $\triangle \mathrm{AUC}^{0 \rightarrow 90}:-40.5 ;-129.7-92.61 \mathrm{mU} * \mathrm{~min} / \mathrm{l}$; $p<0.05)$ or SS-14 $\left(\Delta \mathrm{AUC}^{0 \rightarrow 90}:-3.4 ;-94.1-51.5\right.$ $\mathrm{mU} * \mathrm{~min} / \mathrm{l} ; p<0.05$ ) co-administration (Fig. 3).

A significant rebound effect on insulin levels after infusion withdrawal of either CST-17 $\left(\Delta\right.$ peak $^{105 \rightarrow 120}$ over time 90': 16.8; 14.5-34.1 mU/1; $p<0.05)$ or CST-14 $\left(\Delta\right.$ peak $^{105 \rightarrow 120}$ over time $90^{\prime}: 13.9 ; 10.7-19.1 \mathrm{mU} / \mathrm{l}$; $p<0.05)$ or SS-14 $\left(\Delta\right.$ peak $^{105 \rightarrow 120}$ over time $90^{\prime}: 13.7$; 7.4-24.9 mU/1; $p<0.05)$ were observed even after the ghrelin tests (Fig. 3).

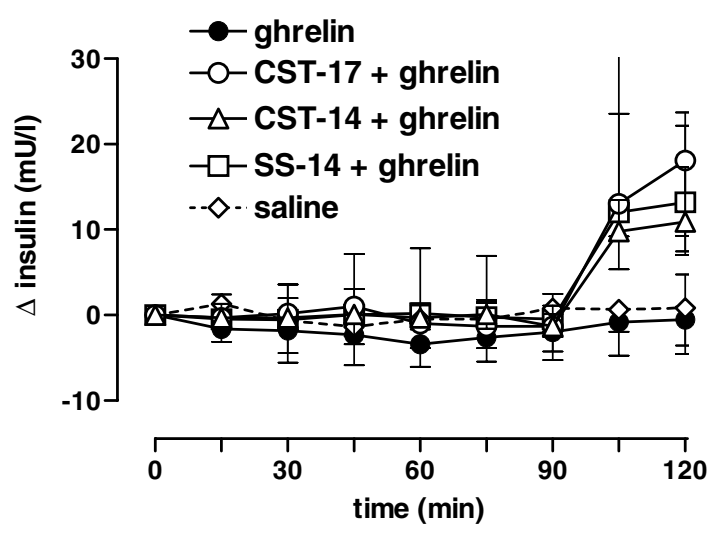

Fig. 3. Median, 3rd and 97th centiles of the insulin responses to ghrelin $\left(1.0 \mu \mathrm{g} / \mathrm{kg}\right.$ iv as a bolus at $\left.0^{\prime}\right)$ alone or in coadministration with CST-17 $\left(2.0 \mu \mathrm{g} / \mathrm{kg} / \mathrm{h}\right.$ iv from $-30^{\prime}$ to $\left.+90^{\prime}\right)$ or CST-14 $\left(2.0 \mu \mathrm{g} / \mathrm{kg} / \mathrm{h}\right.$ iv from $-30^{\prime}$ to $\left.+90^{\prime}\right)$ or SS-14 $\left(2.0 \mu \mathrm{g} / \mathrm{kg} / \mathrm{h}\right.$ iv from $-30^{\prime}$ to $\left.+90^{\prime}\right)$ in 6 normal subjects.

On the other hand, ghrelin also induced an increase in glucose levels $\left(\Delta \mathrm{AUC}^{0 \rightarrow 90}: 600.0 ; 224.7-3087.6\right.$ $\mathrm{mg} * \mathrm{~min} / \mathrm{dl} ; p<0.01)$ that was not modified by either CST-17 (817.5; 295.8-866.9 $\mathrm{mg} * \mathrm{~min} / \mathrm{dl}), \quad$ CST-14 $\left(\triangle \mathrm{AUC}^{0 \rightarrow 90}: 420.0 ; 30.3-941.7 \mathrm{mg} * \mathrm{~min} / \mathrm{dl}\right)$ or $\mathrm{SS}-14$ $\left(\Delta \mathrm{AUC}^{0 \rightarrow 90}:-82.5 ;-716.2-1608.5 \mathrm{mg} * \mathrm{~min} / \mathrm{dl}\right)$ infusion.

\subsection{Side effects}

A transient facial flushing was observed in three subjects after the administration of GHRH. Four subjects felt a peculiar sudden increase in appetite after ghrelin administration. CST as well as SS administration elicited no side effect.

\section{Discussion}

The results of the present study show for the first time that human CST-17 exerts endocrine and metabolic activities in humans. Specifically, our present data demonstrate that CST-17 shares with CST-14 and SS-14 the same inhibitory effect on spontaneous insulin secretion as well as on spontaneous and GHRH- or ghrelin-stimulated GH secretion in humans.

As previously reported for CST-14 and SS-14 [23], the GH-releasing activity of ghrelin is partially resistant also to CST-17 that, however, does not modify the stimulatory effect of ghrelin on both lactotroph and corticotroph secretion. An inhibitory effect on insulin secretion is recorded also after the acute administration of ghrelin that, however, does not modify that of CST-17, CST-14 and SS-14. On the other hand, CST-17 as well as CST14 and SS-14, does not modify the ghrelin-induced increase in glucose levels.

CST-17 is a neuropeptide able to bind all SS receptors subtypes with high affinity because of a marked structural homology with SS itself $[3,4,10]$. Our previous 
studies showed that in humans CST-14 displays the classical effects of SS-14 inhibiting to the same extent both spontaneous and GHRH-, ghrelin- or hexarelinstimulated GH secretion as well as spontaneous insulin and ghrelin secretion $[17,22,23]$. An inhibitory action of CST-14 on GH secretion similar to that of SS-14 has also recently been demonstrated in rats [23].

The effects of the administration of the human CST17 form had never been studied so far and it was interesting to verify whether this molecular form shares or not the same actions as rat CST and as native somatostatin. The similar high affinity of CST-17, -14, and -29 to SS receptors as well as to the GHS receptor suggested similar biologic activity but this was not necessarily obvious since the mutation of one single amino acid is enough to completely change the biological activity of a peptide $[4,10,25]$.

Our present findings show that CST-17, like CST-14 and SS-14, almost abolishes the GH response to GHRH but only blunts the stimulatory effect of ghrelin on GH secretion, in agreement with previous reports showing that ghrelin, which acts, at least partially, via functional antagonism of SS activity, is refractory to the inhibitory effect elicited by the activation of SS receptors [19,22].

On the other hand, at least in these experimental conditions, CST-17 does not modify the lactotroph and corticotroph responsiveness to ghrelin, in agreement with previous data showing that the activation of SS receptors does not influence the lactotroph and corticotroph responses to hexarelin, a synthetic GHS, as well as to ghrelin [19].

Moreover, CST-17, like CST-14 and SS-14 infusion, clearly inhibits insulin secretion which, though to a lower extent, is also reduced by the acute administration of ghrelin [20]. Interestingly, ghrelin administration during CST-17, CST-14 or SS infusion does not modify their inhibitory action on insulin levels; these findings suggest that the negative influence of acute ghrelin administration on beta cell secretion might be mediated by enhanced somatostatinergic activity [20]. In agreement with this hypothesis, a clear interplay between ghrelin and SS secretion has already been reported. In fact, native SS as well as synthetic SS analogues markedly inhibit ghrelin secretion [21,26-28] and, on the contrary, the acute ghrelin administration increases circulating SS levels [29].

The present study shows again that the acute administration of ghrelin raises glucose levels and shows that this effect is not abolished by CST-17, CST-14 or SS infusion. The hyperglycemic effect of ghrelin is unlikely to be explained by variations of insulin or glucagon secretion and more likely reflects a direct action at the hepatic level $[20,30]$.

In conclusion, this study demonstrates that human CST-17 and rat CST-14 exert the same endocrine activities as SS in humans, likely reflecting their common activation of SS receptors. The activation of SS receptors seems to functionally mask the ability of CST-17 as well as of CST-14, to bind with high affinity the GHS-R too and thus to show some peculiar interaction with ghrelin receptor and activity. In order to clarify this point, studies with a new CST analogue that does not show any binding affinity to SS receptors but maintains its ability to bind the GHS-R are currently being carried out.

\section{Acknowledgements}

The present study was supported by MIUR (Ministero Istruzione Università e Ricerca, Rome, Italy), Eureka (Peptido project 1923) and FSMEM (Fondazione per lo Studio delle Malattie Endocrino-Metaboliche, Turin, Italy). The research activity of Fabio Broglio at the Division of Endocrinology and Metabolism of the Erasmus University of Rotterdam is supported by a grant of the GH/IGF-I Society.

\section{References}

[1] L. de Lecea, J.R. Criado, O. Prospero-Garcia, et al., A cortical neuropeptide with neuronal depressant and sleep-modulating properties, Nature 381 (1996) 242-245.

[2] L. de Lecea, P. Ruiz-Lozano, P.E. Danielson, et al., Cloning, mRNA expression, and chromosomal mapping of mouse and human preprocortistatin, Genomics 42 (1997) 499-506.

[3] S. Fukusumi, C. Kitada, S. Takekawa, et al., Identification and characterization of a novel human cortistatin-like peptide, Biochem. Biophys. Res. Commun. 232 (1997) 157-163.

[4] A.D. Spier, L. de Lecea, Cortistatin: a member of the somatostatin neuropeptide family with distinct physiological functions, Brain Res. Brain Res. Rev. 33 (2000) 228-241.

[5] L. de Lecea, J.A. del Rio, J.R. Criado, et al., Cortistatin is expressed in a distinct subset of cortical interneurons, J. Neurosci. 17 (1997) 5868-5880.

[6] V.A. Dalm, P.M. van Hagen, P.M. van Koetsveld, et al., Cortistatin rather than somatostatin as a potential endogenous ligand for somatostatin receptors in the human immune system, J. Clin. Endocrinol. Metab. 88 (2003) 270-276.

[7] M. Papotti, E. Tarabra, E. Allia, et al., Presence of cortistatin in the human pancreas, J. Endocrinol. Invest. 26 (2003) RC15RC18.

[8] H.J. Kreienkamp, Molecular biology of the receptors for somatostatin and cortistatin, Res. Probl. Cell Different 26 (1999) 215-237.

[9] R.D. Cone, M.J. Low, J.K. Elmquist, J.L. Cameron, Neuroendocrinology, in: P.R. Larsen, P. Reed, H.M. Kronenberg, S. Melmed, K.S. Polomsky (Eds.), Williams Textbook of Endocrinology, 10th ed., Elsevier Science, Philadelphia, 2003, pp. 81-176.

[10] S. Siehler, K. Seuwen, D. Hoyer, [125I]Tyr10-cortistatin14 labels all five somatostatin receptors, Naunyn Schmiedebergs Arch. Pharmacol. 357 (1998) 483-489.

[11] A. Vasilaki, C. Lanneau, P. Dournaud, L. de Lecea, R. Gardette, J. Epelbaum, Cortistatin affects glutamate sensitivity in mouse hypothalamic neurons through activation of sst2 somatostatin receptor subtype, Neuroscience 88 (1999) 359-364.

[12] M. Sanchez-Alavez, M. Gomez-Chavarin, L. Navarro, et al., Cortistatin modulates memory processes in rats, Brain Res. 858 (2000) 78-83. 
[13] M. Calbet, A. Guadano-Ferraz, A.D. Spier, et al., Cortistatin and somatostatin mRNAs are differentially regulated in response to kainate, Brain Res. Mol. Brain Res. 72 (1999) $55-64$.

[14] N. Robas, E. Mead, M. Fidock, MrgX2 is a high potency cortistatin receptor expressed in dorsal root ganglion, J. Biol. Chem. 278 (2003) 44400-44444.

[15] R. Deghenghi, M. Papotti, E. Ghigo, G. Muccioli, Cortistatin, but not somatostatin, binds to growth hormone secretagogue (GHS) receptors of human pituitary gland, J. Endocrinol. Invest. 24 (2001) RC1-RC3.

[16] M. Kojima, H. Hosoda, K. Kangawa, Purification and distribution of ghrelin: the natural endogenous ligand for the growth hormone secretagogue receptor, Horm. Res. 56 (Suppl. 1) (2001) 93-97.

[17] R. Deghenghi, F. Broglio, M. Papotti, G. Muccioli, E. Ghigo, Targeting the ghrelin receptor: orally active GHS and cortistatin analogs, Endocrine 22 (2003) 13-18.

[18] M. Kojima, H. Hosoda, Y. Date, M. Nakazato, H. Matsuo, K. Kangawa, Ghrelin is a growth-hormone-releasing acylated peptide from stomach, Nature 402 (1999) 656-660.

[19] G. Muccioli, M. Tschop, M. Papotti, R. Deghenghi, M. Heiman, E. Ghigo, Neuroendocrine and peripheral activities of ghrelin: implications in metabolism and obesity, Eur. J. Pharmacol. 440 (2002) 235-254.

[20] F. Broglio, C. Gottero, A. Benso, et al., Ghrelin and the endocrine pancreas, Endocrine 22 (2003) 19-24.

[21] F. Broglio, P. Van Koetsveld, A. Benso, et al., Ghrelin secretion is inhibited by either somatostatin or cortistatin in humans, J. Clin. Endocrinol. Metab. 87 (2002) 4829-4832.
[22] F. Broglio, E. Arvat, A. Benso, et al., Endocrine activities of cortistatin-14 and its interaction with GHRH and ghrelin in humans, J. Clin. Endocrinol. Metab. 87 (2002) 3783-3790.

[23] A. Benso, C. Gottero, F. Prodam, et al., Effects of cortistatin-14 and somatostatin-14 on the endocrine response to hexarelin in humans, J. Endocrinol. Invest. 26 (2003) 599-603.

[24] R. Deghenghi, R. Avallone, A. Torsello, G. Muccioli, E. Ghigo, V. Locatelli, Growth hormone-inhibiting activity of cortistatin in the rat, J. Endocrinol. Invest. 24 (2001) RC31-RC33.

[25] J.J. Kopchick, C. Parkinson, E.C. Stevens, P.J. Trainer, Growth hormone receptor antagonists: discovery, development, and use in patients with acromegaly, Endocr. Rev. 23 (2002) 623-646.

[26] A.L. Barkan, E.V. Dimaraki, S.K. Jessup, K.V. Symons, M. Ermolenko, C.A. Jaffe, Ghrelin secretion in humans is sexually dimorphic, suppressed by somatostatin, and not affected by the ambient growth hormone levels, J. Clin. Endocrinol. Metab. 88 (2003) 2180-2184.

[27] M. Shimada, Y. Date, M.S. Mondal, et al., Somatostatin suppresses ghrelin secretion from the rat stomach, Biochem. Biophys. Res. Commun. 302 (2003) 520-525.

[28] H. Norrelund, T.K. Hansen, H. Orskov, et al., Ghrelin immunoreactivity in human plasma is suppressed by somatostatin, Clin Endocrinol (Oxf) 57 (2002) 539-546.

[29] M. Arosio, C.L. Ronchi, C. Gebbia, V. Cappiello, P. Beck-Peccoz, M. Peracchi, Stimulatory effects of ghrelin on circulating somatostatin and pancreatic polypeptide levels, J. Clin. Endocrinol. Metab. 88 (2003) 701-704.

[30] F. Broglio, A. Benso, C. Castiglioni, et al., The endocrine response to ghrelin as a function of gender in humans in young and elderly subjects, J. Clin. Endocrinol. Metab. 88 (2003) 1537-1542. 